\title{
Diet and Nutritional Status of Rural Preschool Children in the State of Orissa
}

\author{
Ch. Gal Reddy, N. Arlappa, R. Hari Kumar, Sharad Kumar, G.N.V. Brahmam, \\ N. Balakrishana and K. Vijayaraghavan \\ Field Division, National Institute of Nutrition, Jamai Osmania (P), Hyderabad 500 007, \\ Andhra Pradesh, India
}

KEYWORDS Anthropometry. Foods. Malnutrition. Nutrients. RDA. Underweight

\begin{abstract}
The data on diet and nutritional status of preschool children at State level is available, however the same is not available at district level for planning appropriate action programmes at that level. Hence in keeping view of this objective the present paper focused on to assess the diet and nutritional status of rural preschool children at district level in the State of Orissa. This study was conducted in rural areas of 30 districts in the State of Orissa. Dietary history was obtained from 1,605 preschool children and about 6,803 children (1-6 Yrs) were covered for anthropometry and clinical examination. The data revealed that the mean intakes of majority of foods except cereals and millets, roots and tubers and vegetables were below the recommended dietary intakes in both the age groups of preschool children. Similarly, in general, the intakes of majority of nutrients were below the RDA. The overall prevalence of Kwashiorkor and Marasmus was $1.1 \%$ each. The prevalence of Bitot's spots was $2.7 \%$. About $63 \%$ of preschool children were stunted and underweighed. Majority of preschool children was subsisting on inadequate diets and the diets were grossly deficient of micronutrients such as riboflavin, vitamin A and iron. The poor dietary intakes are reflected by higher prevalence of stunting and underweight.
\end{abstract}

\section{INTRODUCTION}

India accounts for about $40 \%$ of undernourished children in the World, contributing significantly to the high morbidity and mortality in the country (James Levinson 1998). A recent appraisal of diet and nutrition situation in rural India by National Nutrition Monitoring Bureau (2001) revealed that about 45 percent of the preschool children are undernourished (weight for age $<75 \%$ of standard) while about $62 \%$ are stunted (height for age < Median-2SD of standard). About $47 \%$ of the adults had Chronic Energy Deficiency (CED, BMI <18.5).

The National Plan of Action on nutrition (under National Nutrition Policy 1993 and 1995) aims at bringing down the prevalence of existing undernutrition among children by half and low birth weight to less than $10 \%$. Data on nutritional status of the community at district level is essential for planning appropriate action programmes at that level.

A survey was hence carried out in the State of Orissa during 1995-96 at the request of Directorate of Women and Child Development (DWCD), Government of India, to assess diet and nutritional situation of rural population at the district level.

The State of Orissa has a total population of 367 millions (Census of India, 2001) contri- buting to $3.6 \%$ of the country's population. The State has second highest proportion of tribal population (22\%) after the State of Madhya Pradesh as against the national average $8 \%$. The State of Orissa is socio-economically much backward as compared to most of the other States in the country.

Objective: To assess the diet and nutritional status of rural preschool children at district level in the State of Orissa.

\section{MATERIAL AND METHODS}

Sampling Design: The survey was carried out in all the 30 districts of the State. In each district, twenty villages were selected, giving due representation to all the blocks/ Taluks in the district, by adopting systematic random sampling (SRS) procedure, coupled with probability proportion to size (PPS) (Cochran, 1972).

In each village, five clusters of four households (HHs) each, i.e., a total of $20 \mathrm{HHs}$, were selected by adopting 'cluster sampling' procedure, by dividing it into geographical regions/parts, considering a group of households/ streets/mohallas/area as one group. Scheduled Caste/Scheduled Tribe population, considered to be socially and economically backward, who often live together in the village, formed one of the clusters. While one cluster was selected from 
$\mathrm{SC} / \mathrm{ST}$ region, four clusters were selected from the rest of the regions. From each of these five, the first household was chosen by random start and four contiguous households were covered for survey. Thus, in the five clusters, a total of 20 households (4 HHs/cluster) were surveyed in each village.

Demographic and socio-economic particulars of all the selected households surveyed were collected, using pre-coded and pre-tested proforma. Individual intakes in terms of cooked foods and nutrients were assessed in every alternate household by using 24-hour recall method of diet survey using standardized cups ( Thimmayamma et al., 1969). The nutritive value of raw foods was calculated using food consumption tables ( Gopalan et al., 1993) .Anthropometrical measurements such as height and weight were taken on all the preschool children in the selected HHs, using standard equipment by adopting standard procedures (Weiner and Lourie,1969). Children were also examined for clinical signs of nutritional deficiency disorders. All the investigators were trained and standardised in the methodology of diet surveys, anthropometry and clinical assessment to ensure that inter and intraindividual variations were within the acceptable limits. In this communication are presented data on dietary intakes and anthropometry of 1-6 years children were utilized.

Food and Nutrient Intake of Preschool Children: The average daily intakes of various foods were calculated for 1-3 years and 4-6 years age old children. The mean Nutrient intakes were calculated. The food intakes were compared with the balanced diets recommended by the ICMR (1981) and nutrient intakes were compared with the recommended dietary allowances for Indians (ICMR, 1990).

Anthropometry: The age / sex wise heights and weights of children, pooled for all the districts were compared with NCHS median values (Hamill et al.,1979) and were categorized into different grades of nutritional status by SD classification according to 'weight for age', 'height for age' and 'weight for height'. The results were compared with the figures reported by National Nutrition Monitoring Bureau survey, 1999.

The results are also compared between the regions. For this purpose three regions were categorized viz central region (Cuttack,
Jagatsingpur, Kendrapara, Jajpur, Balosore, Bhadrak, Mayurbhanj, Puri, Khordha and Nayagarh), Southern region (Ganjam, Gajpati, Boudh, Phulbhani, Koraput, Nabarangpur, Rayagada, Malkangiri, Kalahandi, and Nawapada) and Northern region (Sambalpur, Baragarh, Deogarh, Jharsuguda, Sundergarh, Balangir, Sonepur, Dhenkanal, Angul, and Kheonjhar) to study the regional variations if any in nutritional status of preschool children.

The foods and nutrient intakes by children (1-6 years) and their nutritional status are analyzed for all the districts.

The nutritional status and percent of RDA of protein and energy intakes of children pooled for all the districts was compared with different socio-economic and demographic indicators such as community, type of house, land holdings, annual per capita income etc.

With respect to communities, nutritional status of SC/ST and other communities was compared. The type of house is one of the generally accepted indices to determine socioeconomic status of the inhabiting household. Comparisons were made among children living in Kutcha, semi-pucca and reinforced cement concrete (RCC) houses. The relationship between nutritional status and land holdings was carried out by considering the size of cultivable land in possession, the farmers marginal $(<2.5$ acres) and small (2.5-5 acres) and large farmers ( $\geq 5$ acres).

Statistical Analysis: Descriptive analysis was performed using the windows version of SPSS, Version-10 (1999). The data was analyzed by stratifying the pre-school children into two age groups of 1-3 years and 4-6 years. Means of various food and nutrient intakes were calculated for each age group. Chi-square analysis was performed to study the association between nutritional status of pre-school children with socioeconomic variables and to compare the same with the result of the NNMB survey for the state of Orissa.

\section{RESULTS}

Coverage: A total of 11,984 households (HHs) from 600 villages from 30 districts were covered for the survey in the state of Orissa. Data on food and nutrient intake was collected from a sub sample of 5,931 HHs covering a total of 1,605 children (1-6 yrs). About 6803 preschool 
children (1-6 yrs) from 11,984 HHs were covered for anthropometry and clinical examination.

Demographic and Socio-economic Profile: About $28 \%$ of the households belonged to Scheduled Tribes, while about $23 \%$ belonged to Scheduled Castes. The proportion of Scheduled Tribes was highest in the district of Malkangiri and lowest in the district of Jagatsinghpur. The proportion of Scheduled Caste ranged from a low $4.5 \%$ in the district of Mayurbhanj to a high $38 \%$ in the district of Bhadrak. About $65 \%$ of the sample lived in kutcha houses. About $33 \%$ of the households surveyed were land less. The average family size was 5.2 for the State, which ranged from a low 4 in Jharsuguda district, to a high 6.6 Jajpur.

The average per capita annual income of the HHs was Rs.3,240/-, which ranged from a low Rs.2,276/- in the district of Nawapara to high Rs.4,580/- in the district of Jharsiguda. It was much lower than the National average of
Rs.11,554/- (Statistical abstract of Andhra Pradesh,1999). The proportion of HHs with per capita annual income of less than Rs.5,000/- was about $85 \%$ for the State and it ranged from a low $67.5 \%$ in Jharsuguda to a high $94.5 \%$ in the district of Kalahandi.

Food and Nutrient Intakes of 1-6 years Children: The average intake of different foodstuffs by age groups is presented in Tables 1 and 2 .

In general, the average intake of all the foods except cereals and millets, roots and tubers and other vegetables was lower than the RDI in both 1-3 and 4-6 year age groups. The consumption of cereals and millets in 1-3 year age group was more than the RDA in $50 \%$ of the districts and, in the case of 4-6 year age group, it was about $63 \%$ of the districts.

The average intake of different nutrients by age is given in Tables 3 and 4 . The mean consumption of all the important nutrients was below the RDA in 1-3 years age group. In none

Table 1: Average intake of foodstuffs (g/day) among 1-3 year children

\begin{tabular}{|c|c|c|c|c|c|c|c|c|c|}
\hline $\begin{array}{l}\text { Name of the } \\
\text { districts }\end{array}$ & $\begin{array}{l}\text { Number } \\
\text { of indivi- } \\
\text { duals }\end{array}$ & $\begin{array}{l}\text { Cereals } \\
\text { and } \\
\text { millets }\end{array}$ & $\begin{array}{l}\text { Pulses } \\
\text { and } \\
\text { legumes }\end{array}$ & $G L V$ & $\begin{array}{l}\text { Roots } \\
\text { and } \\
\text { tubers }\end{array}$ & $\begin{array}{l}\text { Other } \\
\text { vege- } \\
\text { tables }\end{array}$ & $\begin{array}{l}\text { Milk and } \\
\quad \text { milk } \\
\text { products }\end{array}$ & $\begin{array}{l}\text { Fats } \\
\text { and } \\
\text { oils }\end{array}$ & $\begin{array}{c}\text { Sugar } \\
\text { and } \\
\text { jaggery }\end{array}$ \\
\hline Angul & 30 & 200 & 16 & 28 & 41 & 55 & 15 & 4 & 3 \\
\hline Balangir & 38 & 237 & 23 & 8 & 21 & 51 & 13 & 7 & 3 \\
\hline Balasore & 26 & 243 & 9 & 15 & 42 & 46 & 32 & 4 & 20 \\
\hline Baragarah & 31 & 237 & 36 & 7 & 29 & 38 & 6 & 6 & 17 \\
\hline Boudh & 28 & 226 & 27 & 32 & 24 & 47 & 2 & 5 & 3 \\
\hline Bhadrak & 30 & 205 & 14 & 15 & 73 & 32 & 3 & 3 & 1 \\
\hline Cuttack & 25 & 101 & 11 & 27 & 35 & 29 & 36 & 3 & 6 \\
\hline Deogarh & 35 & 222 & 7 & 20 & 28 & 24 & 4 & 4 & 1 \\
\hline Dhenkanal & 26 & 145 & 14 & 3 & 52 & 39 & 30 & 2 & 13 \\
\hline Ganjam & 27 & 179 & 11 & 7 & 86 & 53 & 0 & 6 & 2 \\
\hline Gajapati & 41 & 163 & 26 & 9 & 24 & 33 & 2 & 3 & 2 \\
\hline Jagatsinghpur & 14 & 87 & 6 & 9 & 32 & 11 & 14 & 3 & 1 \\
\hline Jajpur & 32 & 165 & 12 & 14 & 71 & 34 & 59 & 5 & 16 \\
\hline Jharsuguda & 11 & 135 & 14 & 32 & 31 & 67 & 98 & 5 & 8 \\
\hline Kalahandi & 28 & 185 & 18 & 15 & 25 & 18 & 12 & 6 & 3 \\
\hline Kendrapara & 31 & 198 & 4 & 17 & 35 & 51 & 10 & 3 & 4 \\
\hline Keonjhar & 24 & 181 & 8 & 28 & 79 & 39 & 3 & 3 & 5 \\
\hline Khurda & 21 & 120 & 7 & 1 & 49 & 25 & 20 & 7 & 3 \\
\hline Koraput & 33 & 129 & 12 & 11 & 20 & 24 & 6 & 1 & 1 \\
\hline Malkangiri & 22 & 100 & 7 & 12 & 10 & 35 & 0 & 2 & 0 \\
\hline Mayurbhanj & 36 & 195 & 6 & 33 & 25 & 31 & 0 & 2 & 2 \\
\hline Nowrangpur & 39 & 237 & 28 & 22 & 19 & 28 & 9 & 3 & 20 \\
\hline Nawapara & 41 & 169 & 15 & 18 & 20 & 68 & 2 & 3 & 12 \\
\hline Nayagarh & 19 & 118 & 4 & 12 & 53 & 27 & 1 & 7 & 5 \\
\hline Phulbani & 33 & 198 & 22 & 14 & 15 & 35 & 2 & 1 & 9 \\
\hline Puri & 24 & 116 & 5 & 4 & 39 & 25 & 23 & 5 & 5 \\
\hline Rayagada & 27 & 128 & 9 & 7 & 21 & 30 & 0 & 2 & 2 \\
\hline Sambalpur & 16 & 124 & 12 & 11 & 42 & 49 & 63 & 3 & 7 \\
\hline Sonepur & 12 & 80 & 13 & 3 & 38 & 41 & 15 & 1 & 4 \\
\hline Sundergarh & 12 & 184 & 14 & 18 & 46 & 51 & 3 & 3 & 6 \\
\hline Pooled & 812 & 175 & 15 & 15 & 36 & 38 & 13 & 4 & 6 \\
\hline RDI & & 175 & 35 & 40 & 10 & 20 & 300 & 15 & 30 \\
\hline
\end{tabular}


Table 2: Average intake of foodstuffs (g/day) among 4 - 6 year children

\begin{tabular}{|c|c|c|c|c|c|c|c|c|c|}
\hline $\begin{array}{l}\text { Name of the } \\
\text { districts }\end{array}$ & $n$ & $\begin{array}{l}\text { Cereals } \\
\text { and } \\
\text { millets }\end{array}$ & $\begin{array}{c}\text { Pulses and } \\
\text { legumes }\end{array}$ & $G L V$ & $\begin{array}{c}\text { Roots } \\
\text { and } \\
\text { tubers }\end{array}$ & $\begin{array}{l}\text { Other } \\
\text { vege- } \\
\text { tables }\end{array}$ & $\begin{array}{l}\text { Milk and } \\
\quad \text { milk } \\
\text { products }\end{array}$ & $\begin{array}{l}\text { Fats } \\
\text { and } \\
\text { oils }\end{array}$ & $\begin{array}{c}\text { Sugar } \\
\text { and } \\
\text { jaggery }\end{array}$ \\
\hline Angul & 34 & 285 & 20 & 33 & 59 & 60 & 6 & 3 & 3 \\
\hline Balangir & 25 & 359 & 40 & 9 & 45 & 44 & 12 & 7 & 5 \\
\hline Balasore & 35 & 340 & 10 & 18 & 75 & 45 & 73 & 7 & 18 \\
\hline Baragarah & 32 & 423 & 48 & 14 & 49 & 39 & 12 & 8 & 28 \\
\hline Boudh & 31 & 278 & 42 & 24 & 31 & 43 & 9 & 4 & 6 \\
\hline Bhadrak & 27 & 326 & 10 & 17 & 91 & 37 & 12 & 2 & 9 \\
\hline Cuttack & 27 & 272 & 16 & 35 & 95 & 56 & 1 & 6 & 12 \\
\hline Deogarh & 30 & 373 & 14 & 17 & 49 & 33 & 0 & 4 & 1 \\
\hline Dhenkanal & 32 & 195 & 11 & 18 & 70 & 58 & 13 & 4 & 12 \\
\hline Ganjam & 30 & 275 & 19 & 8 & 100 & 71 & 0 & 6 & 2 \\
\hline Gajapati & 43 & 284 & 22 & 16 & 25 & 44 & 4 & 2 & 3 \\
\hline Jagatsinghpur & 28 & 120 & 14 & 12 & 62 & 18 & 7 & 5 & 3 \\
\hline Jajpur & 46 & 252 & 17 & 13 & 83 & 60 & 16 & 6 & 7 \\
\hline Jharsuguda & 10 & 192 & 21 & 31 & 67 & 129 & 119 & 11 & 13 \\
\hline Kalahandi & 24 & 320 & 17 & 30 & 30 & 31 & 2 & 7 & 3 \\
\hline Kendrapara & 20 & 318 & 10 & 20 & 52 & 70 & 5 & 2 & 9 \\
\hline Keonjhar & 15 & 324 & 4 & 24 & 86 & 49 & 3 & 3 & 5 \\
\hline Khurda & 18 & 222 & 16 & 11 & 58 & 33 & 13 & 11 & 5 \\
\hline Koraput & 25 & 295 & 14 & 19 & 20 & 55 & 1 & 2 & 1 \\
\hline Malkangiri & 24 & 208 & 10 & 13 & 19 & 48 & 0 & 4 & 1 \\
\hline Mayurbhanj & 27 & 313 & 8 & 35 & 34 & 49 & 0 & 3 & 4 \\
\hline Nowrangpur & 27 & 318 & 37 & 28 & 23 & 56 & 15 & 5 & 23 \\
\hline Nawapara & 42 & 257 & 18 & 7 & 28 & 78 & 4 & 3 & 11 \\
\hline Nayagarh & 17 & 239 & 14 & 22 & 57 & 28 & 11 & 9 & 11 \\
\hline Phulbani & 33 & 281 & 22 & 53 & 18 & 36 & 2 & 2 & 7 \\
\hline Puri & 24 & 202 & 6 & 6 & 83 & 27 & 10 & 7 & 4 \\
\hline Rayagada & 33 & 226 & 18 & 11 & 16 & 44 & 0 & 3 & 1 \\
\hline Sambalpur & 6 & 314 & 25 & 10 & 110 & 142 & 14 & 4 & 3 \\
\hline Sonepur & 15 & 217 & 8 & 12 & 84 & 62 & 7 & 3 & 6 \\
\hline Sundergarh & 13 & 285 & 22 & 31 & 98 & 72 & 9 & 5 & 7 \\
\hline Pooled & 793 & 279 & 19 & 20 & 53 & 50 & 11 & 5 & 8 \\
\hline$R D I$ & & 270 & 35 & 50 & 20 & 30 & 250 & 25 & 40 \\
\hline
\end{tabular}

of the districts, the diets of the children satisfied the suggested levels for energy, iron and riboflavin. In only about a third of the districts $(30 \%)$, the consumption of protein was satisfactory. The mean consumption of vitamin A was below RDA in all the districts barring Cuttack, Boudh and Keonjhar. The proportion of children with inadequate intakes was maximum for riboflavin $(71 \%)$ followed by vitamin A (53\%), calcium (51\%) and iron (50\%).

Similarly, among 4-6 year children the intakes of all the nutrients except for thiamin and vitamin-C were below the RDA. In about a third of the districts (37\%), the protein intake was more than the suggested level. In a majority of the districts, the diets of 4-6 year children were inadequate in energy, iron, vitamin $\mathrm{A}$ and riboflavin. The extent of deficit was maximum for riboflavin (70\%) followed by iron $(56 \%)$ and vitamin A (46\%).
Proportion of Households with intake of Nutrients below 70\% of RDA: The district wise proportion of HHs with micro nutrient intakes of $<70 \%$ of RDAs are presented in Figure 1.

The intake of iron was less than $70 \%$ of RDA in a majority of the HHs in most of the districts, the proportion of which ranged from $69 \%$ in the districts of Balasore and Puri to a high $98 \%$ in the district of Malkangiri. Similarly, in case of vitamin-A, the proportion of HHs with the consumption level of $<70 \%$ of RDI ranged from about $56 \%$ in the district of Keonjar to a high of 93\% in Khurda district. With regard to intake of riboflavin, the proportion ranged from a low $73 \%$ in the district of Rayagada to $100 \%$ in the districts of Mayurbhanj, Puri and Keondrapara.

Nutritional Deficiency Signs: Though the number of children covered for clinical assessment is not adequate at district level, the prevalences of clinical forms of nutritional 
Table 3: Average daily intake of nutrients among 1-3 year children

\begin{tabular}{|c|c|c|c|c|c|c|c|c|c|c|c|}
\hline $\begin{array}{l}\text { Name of the } \\
\text { districts }\end{array}$ & $n$ & $\begin{array}{l}\text { Protein } \\
\quad(g)\end{array}$ & $\begin{array}{c}\text { Total } \\
\text { Fat }(g)\end{array}$ & $\begin{array}{c}\text { Energy } \\
\text { (Kcal) }\end{array}$ & $\begin{array}{l}\text { Calcium } \\
\quad(m g)\end{array}$ & $\begin{array}{l}\text { Iron } \\
(m g)\end{array}$ & $\begin{array}{c}\text { Vitamin A } \\
A(\mu g)\end{array}$ & $\begin{array}{l}\text { Thiamin } \\
\text { (mg) }\end{array}$ & $\begin{array}{l}\text { Ribo- } \\
\text { flavin } \\
(\mathrm{mg})\end{array}$ & $\begin{array}{c}\text { Vitamin } C \\
(m g)\end{array}$ & $\begin{array}{c}\text { C Free } \\
\text { Folic } \\
\text { Acid }(\mu g)\end{array}$ \\
\hline Angul & 30 & 21 & 7 & 882 & 175 & 6 & 174 & 0.6 & 0.2 & 33 & 25 \\
\hline Balangir & 38 & 24 & 10 & 1037 & 151 & 5 & 158 & 0.7 & 0.2 & 26 & 34 \\
\hline Balasore & 26 & 28 & 9 & 1123 & 284 & 7 & 237 & 0.7 & 0.3 & 34 & 31 \\
\hline Baragarah & 31 & 30 & 9 & 1145 & 140 & 6 & 137 & 0.7 & 0.3 & 29 & 32 \\
\hline Boudh & 28 & 29 & 8 & 1030 & 234 & 7 & 424 & 0.8 & 0.3 & 38 & 38 \\
\hline Bhadrak & 30 & 26 & 5 & 902 & 217 & 7 & 259 & 0.6 & 0.2 & 35 & 28 \\
\hline Cuttack & 25 & 15 & 9 & 555 & 240 & 5 & 407 & 0.4 & 0.2 & 35 & 20 \\
\hline Deogarh & 35 & 22 & 6 & 908 & 161 & 5 & 229 & 0.6 & 0.2 & 39 & 34 \\
\hline Dhenkanal & 26 & 17 & 6 & 717 & 143 & 9 & 77 & 0.5 & 0.2 & 29 & 19 \\
\hline Ganjam & 27 & 19 & 7 & 839 & 134 & 4 & 73 & 0.6 & 0.2 & 38 & 26 \\
\hline Gajapati & 41 & 21 & 5 & 737 & 146 & 6 & 104 & 0.4 & 0.2 & 18 & 17 \\
\hline Jagatsinghpur & 14 & 11 & 5 & 424 & 181 & 3 & 127 & 0.3 & 0.1 & 15 & 13 \\
\hline Jajpur & 32 & 24 & 11 & 886 & 429 & 8 & 240 & 0.6 & 0.3 & 36 & 22 \\
\hline Jharsuguda & 11 & 21 & 13 & 773 & 352 & 4 & 381 & 0.5 & 0.3 & 74 & 21 \\
\hline Kalahandi & 28 & 21 & 8 & 840 & 202 & 4 & 209 & 0.5 & 0.2 & 21 & 25 \\
\hline Kendrapara & 31 & 17 & 5 & 818 & 91 & 4 & 50 & 0.6 & 0.2 & 39 & 25 \\
\hline Keonjhar & 24 & 19 & 5 & 837 & 221 & 6 & 434 & 0.5 & 0.2 & 78 & 21 \\
\hline Khurda & 21 & 14 & 10 & 617 & 102 & 6 & 33 & 0.4 & 0.2 & 19 & 16 \\
\hline Koraput & 33 & 16 & 3 & 552 & 220 & 6 & 129 & 0.4 & 0.2 & 11 & 16 \\
\hline Malkangiri & 22 & 12 & 3 & 416 & 123 & 3 & 73 & 0.2 & 0.1 & 22 & 14 \\
\hline Mayurbhanj & 36 & 18 & 4 & 786 & 189 & 9 & 323 & 0.5 & 0.2 & 54 & 22 \\
\hline Nowrangpur & 39 & 29 & 6 & 1086 & 399 & 11 & 255 & 0.7 & 0.3 & 33 & 40 \\
\hline Nawapara & 41 & 19 & 5 & 798 & 179 & 7 & 171 & 0.6 & 0.3 & 49 & 24 \\
\hline Nayagarh & 19 & 14 & 8 & 587 & 108 & 6 & 33 & 0.4 & 0.1 & 37 & 16 \\
\hline Phulbani & 33 & 23 & 3 & 849 & 122 & 8 & 124 & 0.6 & 0.2 & 19 & 27 \\
\hline Puri & 24 & 14 & 9 & 588 & 179 & 5 & 54 & 0.4 & 0.1 & 19 & 14 \\
\hline Rayagada & 27 & 13 & 4 & 544 & 206 & 4 & 99 & 0.3 & 0.2 & 9 & 13 \\
\hline Sambalpur & 16 & 18 & 9 & 665 & 248 & 5 & 209 & 0.5 & 0.2 & 28 & 19 \\
\hline Sonepur & 12 & 11 & 3 & 411 & 83 & 2 & 64 & 0.3 & 0.1 & 16 & 13 \\
\hline Sundergarh & 12 & 18 & 5 & 795 & 104 & 6 & 123 & 0.5 & 0.2 & 38 & 26 \\
\hline Pooled & 812 & 20 & 6 & 803 & 195 & 6 & 190 & 0.5 & 0.2 & 32 & 24 \\
\hline$R D I$ & & 22 & & 1240 & 400 & 12 & 400 & 0.6 & 0.7 & 40 & 30 \\
\hline
\end{tabular}

deficiency signs pooled for all the districts is presented. The overall prevalence of kwashiorkor and marasmus the clinical signs of protein energy malnutrition was $1.1 \%$ each. The prevalence of kwashiorkor (1.5\%) and marasmus $(1.3 \%)$ was significantly higher among $1-3$ yrs age group as compared to 4-6 yrs age group (0.6\% each) . The overall prevalence of Bitot spots, an objective sign of vitamin A deficiency was about $2.7 \%$ among the preschool children. The prevalence was significantly higher among 4-6 yrs (4.2\%) as compared to 1-3 yrs age group $(1.4 \%)$. In two thirds of the districts $(60 \%)$, the prevalence of Bitot spots was more than $0.5 \%$, a level suggested by WHO as a public health significance. A spearman rank correlation was computed between consumption of Vitamin A and prevalence of Bitot spot among 1-6 year children which revealed that there was a inverse relationship in intake of Vitamin A and prevalence of Bitot spot however it was statistically not significant. In general, $1.3 \%$ and $3 \%$ of pre-school children had Glossitis and angular stomatitis respectively.

\section{Anthropometry}

Percent distribution pre-school children according to Standard Deviation Classification for height for age, weight for age and weight for height are presented in Table-5-6.

Weight for Age: The overall prevalence of underweight $(<$ Median $-2 \mathrm{SD})$ was about $61 \%$ while that of severe underweight $(<$ median - 3 $\mathrm{SD})$ was about $25 \%$. The prevalence of severe under weight was significantly low $(\mathrm{P}<0.001)$ among 4-6 year children (16.7\%) as compared to $1-3$ year children $(28.2 \%)$ (Table 5). The prevalence of severe underweight among preschool children was marginally higher in the districts of northern region as compared to other two regions in both in 1-3 and 4-6 yrs age groups. 
Table 4: Average daily intake of nutrients among 4-6 years children

\begin{tabular}{|c|c|c|c|c|c|c|c|c|c|c|c|}
\hline $\begin{array}{l}\text { Name of the } \\
\text { districts }\end{array}$ & $n$ & $\begin{array}{l}\text { Protein } \\
\quad(g)\end{array}$ & $\begin{array}{c}\text { Total } \\
\text { Fat }(g)\end{array}$ & $\begin{array}{l}\text { Energy } \\
\text { (Kcal) }\end{array}$ & $\begin{array}{l}\text { Calcium } \\
\text { (mg) }\end{array}$ & $\begin{array}{l}\text { Iron } \\
(m g)\end{array}$ & $\begin{array}{l}\text { Vitamin A } \\
(\mu g)\end{array}$ & $\begin{array}{l}\text { Thiamin } \\
\text { (mg) }\end{array}$ & $\begin{array}{l}\text { Ribo- } \\
\text { flavin } \\
\text { (mg) }\end{array}$ & $\begin{array}{c}\text { Vitamin } C \\
(m g)\end{array}$ & $\begin{array}{c}\text { Free } \\
\text { Folic } \\
\text { Acid }(\mu g)\end{array}$ \\
\hline Angul & 34 & 27 & 5 & 1182 & 154 & 7 & 169 & 0.8 & 0.3 & 54 & 38 \\
\hline Balangir & 25 & 37 & 11 & 1552 & 179 & 9 & 149 & 1.1 & 0.4 & 26 & 48 \\
\hline Balasore & 35 & 40 & 16 & 1573 & 440 & 9 & 338 & 1.0 & 0.4 & 39 & 45 \\
\hline Baragarah & 32 & 48 & 14 & 1932 & 241 & 10 & 222 & 1.2 & 0.5 & 45 & 53 \\
\hline Boudh & 31 & 32 & 8 & 1254 & 250 & 7 & 337 & 0.9 & 0.3 & 31 & 46 \\
\hline Bhadrak & 27 & 33 & 7 & 1366 & 221 & 11 & 319 & 0.9 & 0.3 & 35 & 39 \\
\hline Cuttack & 27 & 33 & 9 & 1247 & 437 & 12 & 609 & 0.8 & 0.3 & 82 & 36 \\
\hline Deogarh & 30 & 34 & 7 & 1480 & 315 & 7 & 209 & 1.0 & 0.3 & 47 & 49 \\
\hline Dhenkanal & 32 & 22 & 7 & 921 & 227 & 7 & 193 & 0.6 & 0.2 & 34 & 25 \\
\hline Ganjam & 30 & 29 & 8 & 1234 & 204 & 6 & 74 & 0.8 & 0.3 & 45 & 35 \\
\hline Gajapati & 43 & 28 & 5 & 1144 & 251 & 7 & 176 & 0.7 & 0.3 & 25 & 25 \\
\hline Jagatsinghpur & 28 & 15 & 6 & 600 & 134 & 5 & 174 & 0.4 & 0.2 & 29 & 20 \\
\hline Jajpur & 46 & 29 & 10 & 1153 & 263 & 11 & 182 & 0.8 & 0.3 & 35 & 32 \\
\hline Jharsuguda & 10 & 31 & 22 & 1166 & 475 & 6 & 472 & 0.8 & 0.5 & 90 & 43 \\
\hline Kalahandi & 24 & 29 & 10 & 1300 & 249 & 6 & 312 & 0.7 & 0.3 & 21 & 34 \\
\hline Kendrapara & 20 & 28 & 5 & 1292 & 250 & 8 & 161 & 0.9 & 0.3 & 47 & 37 \\
\hline Keonjhar & 15 & 29 & 6 & 1328 & 226 & 6 & 250 & 0.8 & 0.3 & 73 & 40 \\
\hline Khurda & 18 & 26 & 13 & 1051 & 348 & 8 & 26 & 0.7 & 0.2 & 30 & 28 \\
\hline Koraput & 25 & 29 & 5 & 1150 & 406 & 10 & 191 & 0.9 & 0.3 & 14 & 33 \\
\hline Malkangiri & 24 & 20 & 6 & 835 & 143 & 4 & 54 & 0.3 & 0.2 & 32 & 19 \\
\hline Mayurbhanj & 27 & 27 & 5 & 1220 & 185 & 10 & 303 & 0.8 & 0.3 & 58 & 33 \\
\hline Nowrangpur & 27 & 35 & 8 & 1434 & 323 & 11 & 261 & 1.0 & 0.4 & 55 & 50 \\
\hline Nawapara & 42 & 26 & 6 & 1134 & 191 & 7 & 121 & 0.8 & 0.3 & 45 & 35 \\
\hline Nayagarh & 17 & 30 & 13 & 1140 & 242 & 11 & 48 & 0.7 & 0.3 & 55 & 31 \\
\hline Phulbani & 33 & 27 & 4 & 1143 & 218 & 8 & 296 & 0.8 & 0.3 & 60 & 38 \\
\hline Puri & 24 & 21 & 12 & 958 & 153 & 7 & 101 & 0.6 & 0.2 & 34 & 26 \\
\hline Rayagada & 33 & 23 & 5 & 920 & 203 & 6 & 156 & 0.6 & 0.3 & 14 & 20 \\
\hline Sambalpur & 6 & 31 & 7 & 1384 & 175 & 8 & 173 & 1.0 & 0.3 & 38 & 42 \\
\hline Sonepur & 15 & 20 & 5 & 936 & 135 & 4 & 179 & 0.6 & 0.2 & 32 & 28 \\
\hline Sundergarh & 13 & 28 & 8 & 1257 & 165 & 6 & 177 & 0.9 & 0.3 & 77 & 40 \\
\hline Pooled & 793 & 29 & 8 & 1211 & 246 & 8 & 218 & 0.8 & 0.3 & 41 & 35 \\
\hline$R D A$ & & 30 & & 1690 & 400 & 18 & 400 & 0.8 & 1.0 & 40 & 40 \\
\hline
\end{tabular}

The prevalence of underweight was more than $75 \%$ in the districts of Jharsuguda, Sonepur and Sundergarh, while in rest of the districts it ranged from $50-75 \%$. The prevalence of severe grade underweight was $25-50 \%$ in about a third $(40 \%)$ of the districts, ranging from $13 \%$ in the district of Ganjam to $45 \%$ in Sundergarh.

Height for Age: The overall prevalence of stunting (< Median-2SD) among preschool children (1-6 yrs) was about 59\%, and that of severe stunting (< Median - 3 SD) was about $30 \%$. The prevalence of severe stunting (Median - 3 SD) was more in 4-6 year children as compared to $1-3$ year children $(32.4 \%)$. The overall prevalence of stunting ( $<$ Median-2SD) was more in the districts of northern region as compared to other regions among 1-3 year children (64\%), while it was more in southern region among 4-6 year children (Table 5). The extent of stunting ranged from $41 \%$ in the district of Nayagarh to $77 \%$ in Sundergarh. In three fourths $(73 \%)$ of the districts surveyed, the prevalence of severe stunting (<Median - 3SD) was about $25-50 \%$ (Table 6).

Weight for Height: This is an index of current nutritional status and is a measure of wasting. In general, $21 \%$ of the children were wasted (<Median - 2SD) with $6.4 \%$ having severe wasting $(<$ Median $-3 \mathrm{SD})$. No significant differences were observed between the children of 1-3 and 4-6 yrs age group. The prevalence of severe wasting was higher in central region $(8.2 \%)$ as compared to other regions among 1-3 year children. While the overall wasting was more in northern region as compared to other regions among 4-6 year children. The prevalence of wasting was $25-50 \%$ in 11districts, while it was less than $25 \%$ in the rest of the districts. Severe wasting ranged from nil in Cuttack to a high $17.4 \%$ in the district of Jagathsinghpur.

Nutritional Status of Pre School Children by Socio-Economic Variables: The overall 


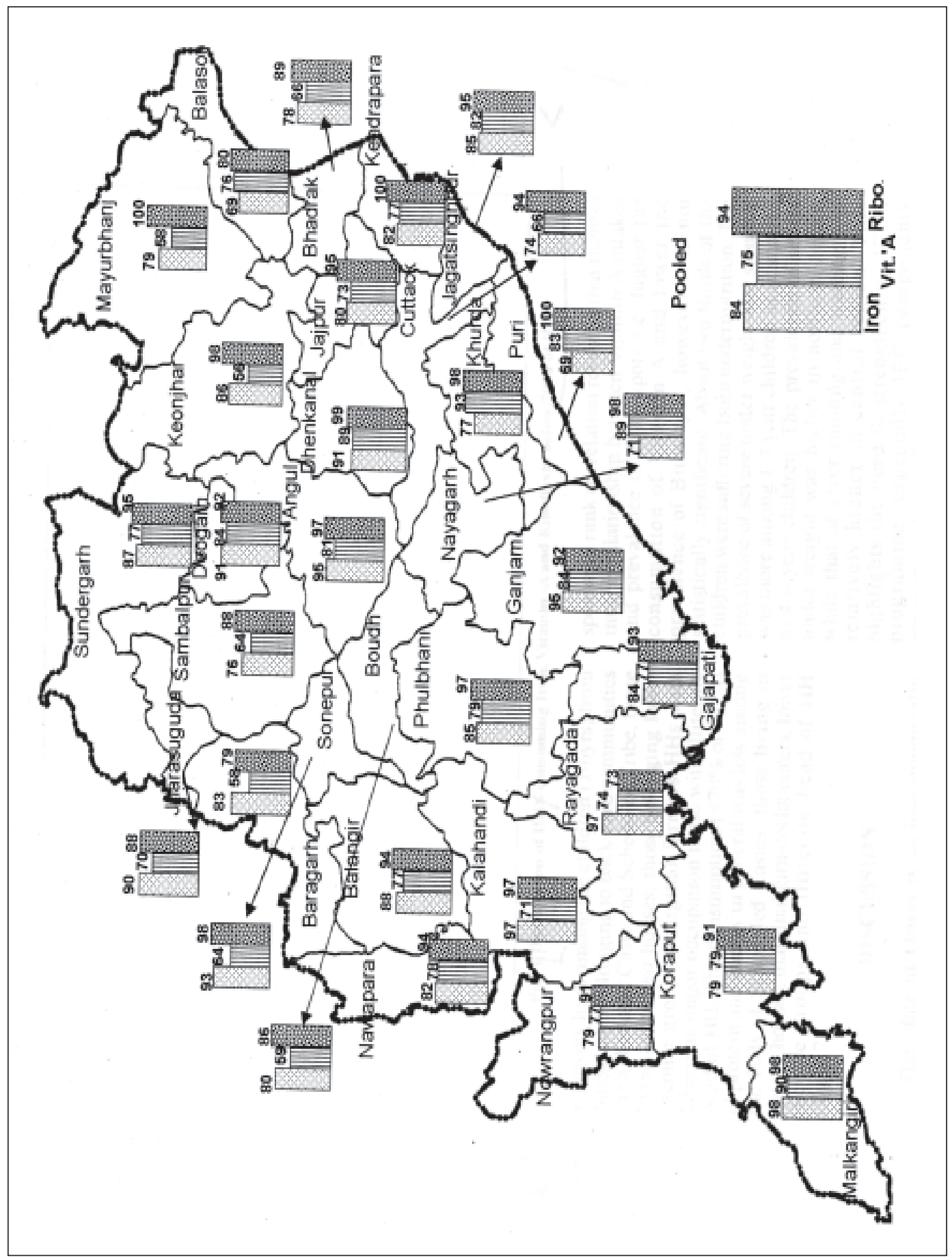

Fig. 1. Distribution of HHs consuming Iron, Vitamin -A and Riboflavin below $<70 \%$ of RDA 
prevalence of underweight (<Median -2SD) was relatively high among the children (1-6yrs) from households belonging to backward communities viz Scheduled Caste and Scheduled Tribe, those living in kutcha houses, those belonging lower income groups, marginal farmers HHs with labour as major occupation those with illiterate head of $\mathrm{HH}$. The consumption ( $<70 \%$ of RDA) of protein and energy in general was low among the HHs of Scheduled Castes, those living in kutcha houses, marginal farmers labourers, lower income groups and illiterate head of $\mathrm{HH}$ (Table 7).

\section{DISCUSSION}

The State of Orissa is socio-economically backward with a majority of HHs living in kutcha houses, with an average per capita income of less than Rs.5,000/- per annum. The major occupation is labour and population is predominantly tribal. The district level survey revealed that all most all the pre-school children were subsisting on inadequate diets. The intake of protective foods such as green leafy vegetables, milk, pulses and legumes and that of fats and oils was grossly inadequate as compared to RDA. The diets were grossly deficient in some of the important micronutrients such as riboflavin, vitamin $\mathrm{A}$ and iron in both age groups. The spearman rank correlation revealed that there is inverse relationship between Vitamin A intakes and prevalence of Bitot spots i.e. higher the consumption of Vitamin A and lower the prevalence of Bitot spot, however it is not statistically significant. About two thirds of the children were suffering from undernutrition. The prevalence of severe under weight and stunting was more among 1-3 year children as compared to 4-6 year children. The prevalence of severe under weight was higher in northern region while that of sever stunting and wasting was relatively higher in central region. This highlights the need to strengthening ICDS programme, especially IEC components concerning breast-feeding and child raring practices.

Nutritional status is major determinant of the health and well being of children. Inadequate diets and infections are associated with poor nutrition (NFHS-II,1999), Nutritional Status of pre-school children has direct impact on school enrollment and dropout rates.
The overall proportion of children with underweight in the State was comparable to the figure reported by NNMB for the state of Orissa (1996-97). The prevalence of stunting in the present study was significantly higher than the figures reported by NNMB for the state of Orissa. The wasting was marginally higher than the corresponding figures for the state of Orissa (NNMB 1996-97) (Table 6). The poor dietary intakes are reflected by higher prevalence of undernutrition among children. The other contributing factors could be poverty, as reflected by higher proportion of kutcha houses, high proportion of HHs with annual per capita income less than Rs.5,000/- and majority of HHs with labour as major occupation. Cross-classification analysis (Table 7) revealed that variables like backward community, poor housing, low per capita income, nil or small land holding, labour and illiteracy were significantly associated with high prevalence of undernutrition. The other factors which could be influencing directly or indirectly the nutritional status of pre-school children such as duration of breast feeding, time of initiation of complementary feeding, extent of immunization, access to health care facilities, availability of protected water supply, environmental sanitation etc. need to be explored.

There is a need to sensitize the community through nutrition and health education, in order to improve the nutritional status of the children. The effort of NGO's as well as Government should be channelised in the direction of improving the household income by providing income generating activities, better housing and sanitary conditions, improving access to health care facilities and literacy status of the community to improve the over all health and nutritional status of the community.

\section{ACKNOWLEDGEMENT}

We acknowledge the secretarial help rendered by Mr. SPV Prasad, Ms G. Madhavi, Ch. Shashidhar Reddy, Santosh Kumar Sahu and S. Raghavendra Rao.

\section{REFERENCES}

Cochran, W.G.: Sampling Techniques. Wiley Eastern Private Limited, New Delhi, pp. 206-233 and pp. 251-255 (1972). Expert Group of the Indian Council of Medical Research: Nutrient Requirements and Recommended Dietary Allowances for Indians. Indian Council of Medical 
Table 5: Distribution (\%) of preschool children by Nutritional Status by Regions: Standard Deviation Classification

\begin{tabular}{|c|c|c|c|c|c|c|c|c|}
\hline \multicolumn{2}{|c|}{ Age Group Region } & \multirow[t]{2}{*}{$n$} & \multicolumn{2}{|c|}{ Weight for Age } & \multicolumn{2}{|c|}{ Height for Age } & \multicolumn{2}{|c|}{ Weight for Height } \\
\hline & & & $\begin{array}{c}<\text { Median } \\
-3 S D\end{array}$ & $\begin{array}{c}<\text { Median } \\
\quad-2 S D\end{array}$ & $\begin{array}{c}<\text { Median } \\
-3 S D\end{array}$ & $\begin{array}{c}<\text { Median } \\
\quad-2 S D\end{array}$ & $\begin{array}{c}<\text { Median } \\
\quad-3 S D\end{array}$ & $\begin{array}{c}<\text { Median } \\
-2 S D\end{array}$ \\
\hline \multirow[t]{4}{*}{$1-3$ yrs } & Central & 1259 & 27.0 & 62.0 & 34.0 & 62.0 & 8.2 & 21.4 \\
\hline & Southern & 1612 & 27.8 & 67.1 & 29.3 & 60.3 & 6.0 & 22.1 \\
\hline & Northern & 1723 & 29.5 & 64.9 & 34.1 & 64.0 & 6.2 & 21.2 \\
\hline & Pooled & 4594 & 28.2 & 64.9 & 32.4 & 62.1 & 6.7 & 21.6 \\
\hline \multirow[t]{4}{*}{ 4-6 yrs } & Central & 629 & 15.6 & 49.3 & 28.3 & 54.5 & 6.2 & 16.9 \\
\hline & Southern & 795 & 15.1 & 54.1 & 23.0 & 50.2 & 5.5 & 17.5 \\
\hline & Northern & 785 & 19.2 & 56.6 & 23.6 & 50.1 & 6.1 & 23.6 \\
\hline & Pooled & 2209 & 16.7 & 53.6 & 24.7 & 51.4 & 5.9 & 19.5 \\
\hline \multirow[t]{5}{*}{$1-6$ yrs } & Central & 1888 & 23.2 & 57.7 & 32.1 & 59.5 & 7.5 & 19.9 \\
\hline & Southern & 2407 & 23.6 & 62.8 & 27.3 & 57.0 & 5.9 & 20.6 \\
\hline & Northern & 2508 & 26.3 & 62.3 & 30.8 & 59.6 & 6.1 & 21.9 \\
\hline & Pooled & 6803 & 24.5 & 61.2 & 29.9 & 58.6 & 6.4 & 20.9 \\
\hline & P-value & & $<0.05$ & $<0.001$ & $<0.001$ & $>0.05$ & $>0.05$ & $>0.05$ \\
\hline
\end{tabular}

Table 6: Distribution (\%) of preschool children by nutritional status: Standard Deviation Classification

\begin{tabular}{|c|c|c|c|c|c|c|c|}
\hline \multirow[t]{2}{*}{ District } & \multirow[b]{2}{*}{$n$} & \multicolumn{2}{|c|}{ Weight for Age } & \multicolumn{2}{|c|}{ Height for Age } & \multicolumn{2}{|c|}{ Weight for Height } \\
\hline & & $\begin{aligned}< & \text { Median } \\
& -3 S D\end{aligned}$ & $\begin{array}{l}<\text { Median } \\
\quad-2 S D\end{array}$ & $\begin{array}{l}<\text { Median } \\
\quad-3 S D\end{array}$ & $\begin{array}{c}<\text { Median } \\
-2 S D\end{array}$ & $\begin{aligned}< & \text { Median } \\
& -3 S D\end{aligned}$ & $\begin{array}{c}<\text { Median } \\
\quad-2 S D\end{array}$ \\
\hline Angul & 340 & 14.1 & 56.5 & 20.0 & 60.3 & 6.2 & 14.7 \\
\hline Balangir & 286 & 23.1 & 60.2 & 24.1 & 56.6 & 5.2 & 18.5 \\
\hline Balasore & 301 & 18.9 & 52.5 & 29.6 & 62.1 & 9.3 & 20.9 \\
\hline Baragarh & 269 & 20.4 & 59.1 & 25.7 & 61.8 & 3.7 & 17.8 \\
\hline Boudh & 306 & 28.1 & 62.2 & 30.7 & 60.1 & 3.3 & 22.9 \\
\hline Bhadrak & 195 & 33.8 & 69.7 & 34.4 & 61.1 & 6.7 & 29.8 \\
\hline Cuttack & 159 & 16.4 & 61.1 & 30.2 & 59.8 & 0.0 & 9.4 \\
\hline Deogarh & 268 & 18.3 & 55.2 & 16.8 & 44.0 & 3.0 & 17.9 \\
\hline Dhenkanal & 284 & 21.8 & 50.3 & 29.2 & 56.3 & 7.4 & 22.2 \\
\hline Ganjam & 134 & 13.4 & 55.9 & 26.9 & 50.0 & 2.2 & 14.9 \\
\hline Gajapati & 283 & 22.6 & 61.8 & 24.4 & 58.7 & 4.6 & 15.9 \\
\hline Jagatsinghpur & 115 & 34.8 & 55.7 & 28.7 & 59.1 & 17.4 & 32.2 \\
\hline Jajpur & 276 & 29.7 & 59.0 & 33.0 & 60.5 & 13.0 & 24.6 \\
\hline Jharsuguda & 251 & 42.2 & 77.7 & 47.0 & 69.7 & 7.6 & 29.9 \\
\hline Kalahandi & 224 & 24.6 & 68.4 & 24.1 & 54.0 & 6.3 & 25.5 \\
\hline Kendrapara & 204 & 22.1 & 62.8 & 45.6 & 61.6 & 7.4 & 12.8 \\
\hline Keonjhar & 201 & 19.9 & 59.7 & 24.9 & 57.2 & 3.5 & 15.9 \\
\hline Khurda & 173 & 17.3 & 56.6 & 30.6 & 58.8 & 5.8 & 15.0 \\
\hline Koraput & 254 & 29.5 & 63.4 & 23.6 & 48.8 & 11.0 & 24.8 \\
\hline Malkangiri & 196 & 29.1 & 64.3 & 23.0 & 50.0 & 15.8 & 33.7 \\
\hline Mayurbhanj & 205 & 19.0 & 55.6 & 31.2 & 53.6 & 3.9 & 16.1 \\
\hline Nowrangpur & 298 & 23.5 & 65.8 & 26.8 & 54.3 & 4.4 & 24.2 \\
\hline Nawapara & 291 & 22.3 & 60.8 & 26.8 & 60.8 & 4.1 & 16.5 \\
\hline Nayagarh & 95 & 18.9 & 45.2 & 24.2 & 41.0 & 7.4 & 25.3 \\
\hline Phulbani & 237 & 16.0 & 51.4 & 31.6 & 72.5 & 2.1 & 9.7 \\
\hline Puri & 165 & 21.2 & 53.9 & 27.3 & 54.6 & 3.0 & 15.7 \\
\hline Rayagada & 184 & 21.7 & 57.6 & 35.3 & 54.3 & 6.5 & 17.4 \\
\hline Sambalpur & 160 & 29.4 & 68.8 & 33.1 & 61.9 & 9.4 & 26.3 \\
\hline Sonepur & 204 & 36.8 & 76.0 & 36.3 & 52.5 & 13.7 & 34.8 \\
\hline Sundergarh & 245 & 45.3 & 82.4 & 58.4 & 76.8 & 4.1 & 27.8 \\
\hline Pooled & 6803 & 24.5 & 61.2 & 29.9 & 58.6 & 6.4 & 20.9 \\
\hline NNMB-96-97 & 2334 & 14.8 & 59.3 & 14.7 & 45.0 & 2.4 & 19.1 \\
\hline$\chi^{2}$ & & $\begin{aligned} & 95.3 \\
& \mathrm{p}<0.001\end{aligned}$ & $\begin{array}{l}2.62 \\
\mathrm{NS}\end{array}$ & $\begin{array}{c}208.8 \\
p<0.001\end{array}$ & $\begin{array}{c}129.96 \\
p<0.001\end{array}$ & $\begin{aligned} & 28.0 \\
\mathrm{p} & <0.001\end{aligned}$ & $\begin{array}{l}3.46 \\
\mathrm{NS}\end{array}$ \\
\hline
\end{tabular}


Table 7: Nutritional profile of rural population according to socio-economic variables

\begin{tabular}{|c|c|c|c|c|c|c|c|}
\hline \multirow[t]{2}{*}{$\begin{array}{l}\text { Socio-economic } \\
\text { indicators }\end{array}$} & & \multicolumn{3}{|c|}{$\begin{array}{l}\text { SD Classification (Weight for age) } \\
\quad \text { ( Children 1-6 years) }\end{array}$} & \multicolumn{3}{|c|}{$\begin{array}{l}\text { Nutrient Intake } \\
<70 \% \text { of } R D A\end{array}$} \\
\hline & & $N$ & $\begin{array}{l}<\text { Median } \\
\quad-3 S D\end{array}$ & $\begin{array}{l}<\text { Median } \\
\quad-2 S D\end{array}$ & $N$ & $\begin{array}{l}\text { Protein } \\
\quad(g)\end{array}$ & $\begin{array}{l}\text { Energy } \\
(\text { Kcal })\end{array}$ \\
\hline \multirow[t]{6}{*}{ Community } & Scheduled Caste & 1184 & 26.9 & 65.8 & 376 & 45.7 & 66.2 \\
\hline & Scheduled Tribe & 1660 & 28.3 & 64.9 & 486 & 40.3 & 59.9 \\
\hline & Backward Caste & 1325 & 21.3 & 59.2 & 406 & 28.8 & 49.3 \\
\hline & Others & 977 & 21.9 & 59.0 & 337 & 32.6 & 54.3 \\
\hline & $\chi^{2}$ & & 26.69 & 21.0 & & & 25.5 \\
\hline & & & $\mathrm{p}<0.001$ & $\mathrm{p}<0.001$ & 29.0 & $\mathrm{p}<0.001$ & $\mathrm{p}<0.001$ \\
\hline \multirow[t]{4}{*}{ Type of House } & Pucca & 3 & 15.1 & 59.2 & 34 & 35.3 & 55.9 \\
\hline & Semi-Pucca & 1594 & 24.1 & 61.0 & 474 & 31.2 & 50.2 \\
\hline & Kutcha & 3459 & 25.6 & 63.3 & 1097 & 39.7 & 60.7 \\
\hline & $\chi_{(2)}^{2}$ & & $\begin{array}{r}6.31 \\
\mathrm{p}<0.01\end{array}$ & $\begin{array}{l}3.0 \\
(\mathrm{NS})\end{array}$ & 10.1, & $\mathrm{p}<0.01$ & $\begin{array}{c}15.0, \\
p<0.001\end{array}$ \\
\hline \multirow{6}{*}{$\begin{array}{l}\text { Land Holdings } \\
\text { (Acres) }\end{array}$} & & & & & & & \\
\hline & $<2.5$ (Marginal Farmers) & 3751 & 24.8 & 62.7 & 1266 & 40.4 & 60.0 \\
\hline & $2.5-5$ (Small Farmers) & 836 & 25.4 & 62.8 & 209 & 24.9 & 49.8 \\
\hline & $\geq 5$ (Larger Farmers) & 559 & 25.0 & 60.4 & 130 & 24.6 & 46.2 \\
\hline & $\chi_{(2)}^{2}$ & & 0.12 & 1.08 & & & 15.1 \\
\hline & \multicolumn{5}{|c|}{ Annual Per capita } & $\mathrm{p}<0.001$ & $\mathrm{p}<0.001$ \\
\hline \multirow{5}{*}{ Income (Rs.) } & $<5000$ & 4654 & 25.7 & 63.2 & 1442 & 38.0 & 58.5 \\
\hline & $5000-10000$ & 409 & 18.1 & 57.7 & 129 & 31.8 & 51.9 \\
\hline & $\geq 10000$ & 83 & 16.9 & 58.2 & 34 & 17.6 & 38.2 \\
\hline & $\bar{\chi}^{2}$ & & 14.6 & 5.7 & & & 7.3 \\
\hline & & & $\mathrm{p}<0.001$ & NS & 7.0, & $\mathrm{p}<0.05$ & $\mathrm{p}<0.05$ \\
\hline \multirow[t]{8}{*}{$\begin{array}{l}\text { Occupation of } \\
\text { head of } \mathrm{HH}\end{array}$} & Landless Agri. Labour & 751 & 25.7 & 64.8 & 194 & 43.3 & 60.8 \\
\hline & Other Labourers & 1640 & 27.1 & 63.9 & 579 & 42.0 & 60.8 \\
\hline & Cultivators & 1627 & 25.9 & 63.0 & 458 & 34.5 & 56.6 \\
\hline & Artisans & 186 & 21.0 & 64.0 & 59 & 25.4 & 44.1 \\
\hline & Service & 415 & 17.6 & 58.8 & 139 & 25.9 & 51.1 \\
\hline & Business & 301 & 21.9 & 53.1 & 113 & 34.5 & 57.5 \\
\hline & $\chi_{(5)}^{2}$ & & $19.8,1$ & $17.1,1$ & & & 10.3 \\
\hline & & & $\mathrm{p}<0.00$ & $\mathrm{p}<0.00$ & 21.6 & $\mathrm{p}<0.001$ & NS \\
\hline \multirow[t]{8}{*}{$\begin{array}{l}\text { Literacy Status } \\
\text { of head of } \mathrm{HH}\end{array}$} & Illiterate & 1810 & 27.3 & 64.8 & 541 & 43.6 & 63.4 \\
\hline & Read and Write & 904 & 26.5 & 65.8 & 208 & 37.5 & 62.5 \\
\hline & Primary & 846 & 24.3 & 62.4 & 253 & 34.0 & 55.3 \\
\hline & Upper Primary & 860 & 23.8 & 59.1 & 301 & 34.9 & 51.5 \\
\hline & High. Secondary & 613 & 20.1 & 57.9 & 224 & 30.4 & 50.0 \\
\hline & College & 113 & 14.2 & 49.6 & 53 & 26.4 & 50.5 \\
\hline & $\chi_{(5)}^{2}$ & & 22.11 & 26.25 & & & 19.9 \\
\hline & & & $\mathrm{p}<0.001$ & $\mathrm{p}<0.001$ & 18.5 & $\mathrm{p}<0.01$ & $\mathrm{p}<0.001$ \\
\hline
\end{tabular}

Research, New Delhi (1990).

Gopalan, C., Ramasastry, B.V. and Balasubramanian S.C.: Nutritive Value of Indian Foods. National Institute of Nutrition, Hyderabad (1993).

Hamill, P.V.V., Drizd, T.A., Johnson, C.L., Reed, R.S., Roche, A.F. and Moore, W.M.: Physical growth: National Centre for Health Statistics (NCHS) pedrcentiles. Am. J. Clin. Nutr, 32: 607-629 (1979).

Indian Council of Medical Research: Recommended Dietary Intakes for Indians. Indian Council of Medical Research, New Delhi (1981).

James, Levinson F.: India - Sector Review of Nutrition Programmes. A background paper prepared for the World Bank, New Delhi (1998).

Ministry of Human Resource Development, Government of India: National Nutrition Policy. Department of Women and Child Development, New Delhi (1993).

Ministry of Human Resource Development, Government of India: National Nutrition Policy. Department of Women and Child Development, New Delhi (1995)

National Nutrition Monitoring Bureau: Report of the Second Repeat Survey - Rural, Hyderabad. National Institute of Nutrition, Indian Council of Medical Research, Hyderabad (1999).

National Nutrition Monitoring Bureau Report of the Rural Survey, Hyderabad: National Institute of Nutrition, Indian Council of Medical Research, Hyderabad (2001).

Statistical Abstract of Andhra Pradesh: Directorate of Economics and Statistics, Government of Andhra Pradesh, Hyderabad (1999).

Thimmayamma, B.V.S. and Hanumantha Rao, D.: A comparative study of the oral questionnaire method with actual observation of the dietary intake of pre-school children, J. Nutr. Diet., 6: 177-181(1969).

Weiner, J.S. and Lourie, J.A. Human Biology. A Guide to Field Methods, International Biological Programme, Hand Book No.9, Blackwell Scientific Publications, Oxford (1969). 